\title{
THE PROGRAMME AND RESULTS OF THE RADIOECOLOGICAL MONITORING OF FRESHWATER ECOSYSTEMS IN THE VICINITY OF ROOPPUR NPP (PEOPLE'S REPUBLIC OF BANGLADESH)
}

\author{
Rena A. Mikailova , Aleksei V. Panov, Dmitry N. Kurbakov
}

Russian Institute of Radiology and Agroecology, Obninsk, Russian Federation

\begin{abstract}
The paper presents an overview of the radioecological monitoring programme of aquatic ecosystems in the vicinity of nuclear power plants and presents the results of its implementation in the 30-km zone of the Rooppur NPP in the People's Republic of Bangladesh. The environmental survey has shown that the content of radionuclides in different components of observed freshwater ecosystems is low and that the radiation situation of the region is safe.
\end{abstract}

Keywords: Radioecological monitoring, freshwater, ecosystems, People's Republic of Bangladesh, Rooppur NPP, environmental monitoring programme

\section{INTRODUCTION}

On the basis of an agreement signed in 2011 between Russia and the People's Republic of Bangladesh, in 2017 the State Atomic Energy Corporation Rosatom began construction of the nuclear power plant (NPP) Rooppur with two VVER1200 power units. The NPP project is being implemented as a part of the development of Bangladesh's nuclear power program in accordance with recommendations and under the supervision of the IAEA [1].

The use of nuclear technologies is associated with the release of a strictly controlled amount of radionuclides into the environment and their subsequent inclusion into biological chains of migration, which causes exposure of living organisms, including humans, to radiation, in addition to natural background radiation. Radionuclides enter the human body through food and water, as well as through inhalation, which determines the formation of internal doses for the population living in the areas adjacent to nuclear power plants and other nuclear fuel cycle objects.

Carrying out the radiation and environmental monitoring before the start of NPP construction of a makes it possible to assess the state of all ecosystems, as well as radiation doses to humans and biota at the background level. This is an important stage since it creates an information basis for further analysis of the impact of nuclear power plants on the environment and humans during the construction of the facility and its operation. It should be noted that in assessing this impact, it is necessary to take into account the environmental pollution from industrial enterprises already existing at the moment and in the vicinity of NPP construction site [2].

Radioecological monitoring is a complex of longterm systemic observations of changes in the environment, which allows for the assessment of the possible influence of NPPs' normal operation and to assess the current level of ecological safety. Data obtained during monitoring should be sufficient for making management decisions regarding the exclusion or the decrease of a possible negative influence of NPPs on the environment in compliance with the standards set by regulations. Radioecological monitoring must be carried out in the NPP site and its observation zone. The size of the observation zone should be determined for normal operating conditions from the conditions of statistical significance of measurements of the parameters of the radiation situation, caused by the natural background and the design parameters of radioactive emissions [3]. Based on this approach, a $30-\mathrm{km}$ observation zone approximately satisfies the condition according to which the dose rate due to permissible emissions from NPP outside the observation zone will be less than $10 \%$ of the standard deviation of the natural background (at the level of 0.01 $\mu \mathrm{Sv} / \mathrm{h})$.

The monitored objects are surface air, terrestrial (natural and agricultural) and aquatic ecosystems, which characterise the region as a whole and are representative in terms of the NPP's impact.

The current paper presents the experience of developing the programme and conducting radioecological monitoring of aquatic ecosystems using the example of Rooppur NPP (People's Republic of Bangladesh).

* mik_r_a@rirae.ru 


\section{METHODOLOGY}

The complexity of observations, the timing of their conduction with the representative hydrological and hydrobiological phases, the determination of indicators characterising the water quality, the composition of bottom sediments, and the state of hydrobiocenosis represent the basis of environmental monitoring of aquatic ecosystems in the NPP vicinity.

The selection of observation points within the framework of environmental monitoring of water ecosystems was carried out with consideration for the results of the reconnaissance survey of the state of water bodies in the NPP's area, the analysis of data on the physicogeographical, morphometric features of water bodies and the analysis of stock data on pollution (including radionuclides) of surface waters, bottom sediments and aquatic organisms, sanitary and hygienic indicators of water quality.

The programme for the study of spatial and temporal features of the hydrological and hydrochemical regime of water bodies in the NPP vicinity is based on IAEA recommendations and Russian legislation in the field of radiation safety [410].

The Rooppur NPP site is located on the east bank of the Padma River, $160 \mathrm{~km}$ north-west of Dhaka. In the 2014-2017 period, the system of radioecological monitoring of the freshwater ecosystems was developed based on a comprehensive survey of the 30$\mathrm{km}$ zone of the Rooppur NPP.

There are significant seasonal differences in climatic characteristics in the vicinity of Rooppur NPP (May-September rainy season and December-March dry season), which significantly affect the water regime of the Padma River, the primary source of water in the region. During the monsoon season, the water in the Padma River rises by 6-8 $\mathrm{m}$, and in winter its level drops to a minimum. Therefore, radioecological monitoring of the observation zone of the Rooppur NPP was conducted in different periods of the year: August (2014), April (2015), December (2016) and June (2017). The investigation of aquatic ecosystems was carried out in the riparian waters of the Padma River, with its streams and canals also examined. A total of 20 observation stations upstream and downstream from the Rooppur NPP site were selected and surveyed. Samples of surface water, sediments and aquatic vegetation (sampled during the growing season) were collected at the control stations. Additionally, samples of drinking (well and tap) water in the $30-\mathrm{km}$ zone were taken.

\subsection{Sampling points of radiation monitoring of water bodies}

The sampling points included observation sites located within a radius of $30 \mathrm{~km}$ from the location of the Rooppur NPP. The selected territory was conditionally divided into three zones with varying degrees of spatial availability. The density of observation sites was higher in an area with a radius of $5 \mathrm{~km}$ from a nuclear power plant. A smaller number of observation sites was chosen in the territory with a radius of up to $10 \mathrm{~km}$, taking into account the available anthropogenic sources of pollutants. Background sections (for NPPs) were installed along the edges of the $30 \mathrm{~km}$ zone (fig. 1). If necessary, the locations and 109 number of sampling points were adjusted during the studies. The sampling points for bottom sediments, higher aquatic vegetation, and surface waters coincided in order to compare the content of the studied pollutant in the components of aquatic ecosystems.

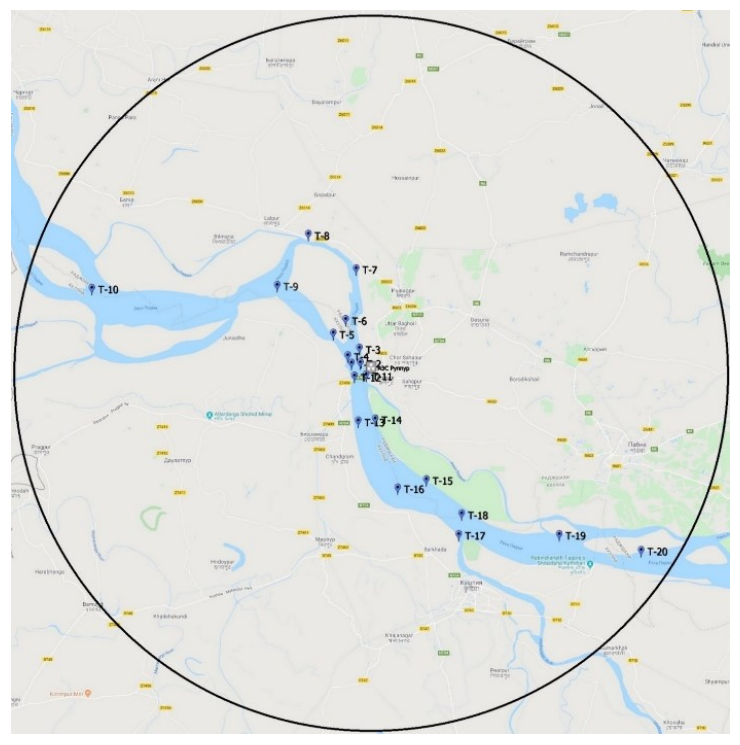

Figure 1. Sampling scheme for water bodies in the vicinity of the Rooppur NPP.

\subsection{Studied indicators}

The samples of the aquatic ecosystem's components were studied to determine the content of natural and artificial radionuclides: ${ }^{40} \mathrm{~K},{ }^{226} \mathrm{Ra},{ }^{232} \mathrm{Th},{ }^{137} \mathrm{Cs},{ }^{90} \mathrm{Sr},{ }^{3} \mathrm{H}$.

\subsection{Water sampling}

Water sampling was carried out using a bathometer. Suspended matter present in the water was separated by a filtering device. Sample analysis was carried out separately for suspended matter and filtrate. The volume of the samples used in the analysis of gamma-emitting radionuclides was determined by the sensitivity of the used spectrometric equipment and was at least 100 litres.

Samples of groundwaters used by the local population for drinking and household needs were taken in the settlements within the $30-\mathrm{km}$ zone at different distances and directions from the NPP from columns, wells, water supply and wells (fig. 2).

\subsection{Sampling of sediments}

Bottom sediment sampling was carried out using a benthic bottom grab DCh-0.025. Samples of bottom sediments were taken from the surface layer of the water body bed at sampling points: one sample per each point with mass (air-dry mass) of at least $0.3 \mathrm{~kg}$. 


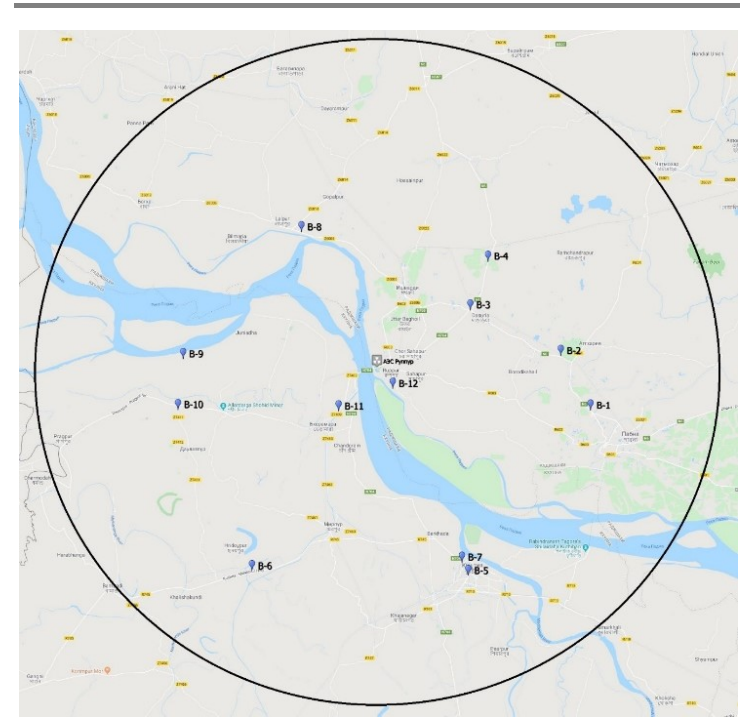

Figure 2. Sampling scheme for groundwaters in the vicinity of the Rooppur NPP.

\subsection{Sampling of hydrobionts}

Higher aquatic vegetation and fish were sampled using species descriptions. The air-dry weight of the selected samples of higher aquatic vegetation was at least $0.2 \mathrm{~kg}$, with wet weight for ichthyofauna being at least $0.5-1.0 \mathrm{~kg}$.

\subsection{Measuring equipment}

The radioactivity measurements were performed in RIRAE Radiation Control and Testing laboratories certified according to the requirements of Rosatom State Corporation and IAEA. The following equipment was used to analyse the concentrations of radionuclides in the components of freshwater ecosystems:

- a low-background gamma-spectrometric complex designed to measure the specific activity of gammaemitting radionuclides in samples of various environmental objects, including industrial samples and food products;

- a low background liquid scintillation system detector, Perkin Elmer - Wallac Quantulus ${ }^{\mathrm{TM}}$ 1220;

- liquid scintillation counter TriCarb 310oTR;

- gamma-spectrometer GAMMA-1P by RPC “ASPEKT”, Russia;

- Sample Oxidizer PerkinElmer 307;

- Multi-Channel Analyzer DeskTop InSpector 1270 by Canberra Industries;

- gamma-spectrometer AccuSpec by Canberra Industries;

- Universal spectrometric complexes "PROGRESS" by Russian LLC "STC Amplituda".

\section{RESULTS OF THE MEASUREMENTS}

The results obtained during the radioecological studies of the freshwater ecosystem's components allows for the obtaining data about the content of natural and artificial radionuclides in the aquatic environment and the evaluation of radiation doses that water users and aquatic organisms experience due to the technogenic changes of background radiation in the region.

The entry of radionuclides into the water of surface water bodies in the absence of nuclear power plants occurs by direct deposition from the air for artificial radionuclides and leaching from the rocks in case of natural ones. Radionuclides that reach large water bodies are rapidly redistributed and usually accumulate in bottom sediments, benthos, aquatic plants and fish. Table 1 presents the results of the radioecological monitoring of aquatic ecosystems in the vicinity of the Rooppur NPP, obtained from 2014 to 2017 [11-14]. It shows maximal and minimal values measured after sampling.

Table 1. The content of radionuclides in the components of freshwater ecosystems (minimum and maximum values), $\mathrm{Bq} / \mathrm{kg}(\mathrm{L})$

\begin{tabular}{|c|c|c|c|c|c|c|}
\hline Component & $4^{\circ} \mathrm{K}$ & ${ }^{226} \mathrm{Ra}$ & $232 \mathrm{Th}$ & ${ }^{90} \mathrm{Sr}$ & $137 \mathrm{Cs}$ & $3 \mathrm{H}$ \\
\hline \multicolumn{7}{|c|}{ August, 2014} \\
\hline $\begin{array}{l}\text { Surface } \\
\text { water of } \\
\text { Padma }\end{array}$ & $<1.5$ & $<0.5$ & $<0.5$ & $\begin{array}{c}0.002- \\
3.75\end{array}$ & $\begin{array}{l}0.02- \\
0.84\end{array}$ & $\begin{array}{l}0.8- \\
1.29\end{array}$ \\
\hline $\begin{array}{l}\text { Bottom } \\
\text { sediments }\end{array}$ & $\begin{array}{l}570- \\
820\end{array}$ & $42-51$ & $44-71$ & $\begin{array}{l}1.5^{-} \\
2.19\end{array}$ & $\begin{array}{c}0.5^{-} \\
4.2\end{array}$ & $<3$ \\
\hline $\begin{array}{l}\text { Aquatic } \\
\text { flora }\end{array}$ & $<1.5$ & $<0.5$ & $<0.5$ & $\begin{array}{l}2.51- \\
3.54\end{array}$ & $\begin{array}{l}1.8- \\
2.6\end{array}$ & $<3$ \\
\hline $\begin{array}{l}\text { Drinking } \\
\text { water }\end{array}$ & $<1.5$ & $<0.5$ & $<0.5$ & $\begin{array}{c}0.019- \\
0.16\end{array}$ & $\begin{array}{l}0.03^{-} \\
0.08\end{array}$ & $\begin{array}{c}0.42- \\
1.18\end{array}$ \\
\hline \multicolumn{7}{|c|}{ April, 2015} \\
\hline $\begin{array}{l}\text { Surface } \\
\text { water of } \\
\text { Padma }\end{array}$ & $<1.0$ & $<0.4$ & $<0.5$ & $\begin{array}{c}0.003^{-} \\
0.05\end{array}$ & $<0.05$ & $\begin{array}{l}0.77- \\
2.05\end{array}$ \\
\hline $\begin{array}{l}\text { Bottom } \\
\text { sediments }\end{array}$ & $\begin{array}{c}369- \\
721\end{array}$ & $\begin{array}{c}14 \cdot 9^{-} \\
121\end{array}$ & $\begin{array}{c}34 \cdot 5^{-} \\
136\end{array}$ & $\begin{array}{c}0.82- \\
1.98\end{array}$ & $\begin{array}{c}0.6- \\
3.2\end{array}$ & $<3$ \\
\hline $\begin{array}{l}\text { Aquatic } \\
\text { flora }\end{array}$ & $\begin{array}{l}253^{-} \\
1090\end{array}$ & $\begin{array}{l}19.2- \\
24.6\end{array}$ & $\begin{array}{l}31.5^{-} \\
68.3\end{array}$ & $\begin{array}{l}0.91^{-} \\
2.18\end{array}$ & $<9.0$ & $<3$ \\
\hline \multicolumn{7}{|c|}{ December, 2016} \\
\hline $\begin{array}{l}\text { Surface } \\
\text { water of } \\
\text { Padma }\end{array}$ & $\begin{array}{c}0.48- \\
1.77\end{array}$ & $\begin{array}{l}0.1- \\
0.3\end{array}$ & $\begin{array}{l}0.1- \\
0.3\end{array}$ & $\begin{array}{c}0.01- \\
0.21\end{array}$ & $<0.07$ & $<3$ \\
\hline $\begin{array}{l}\text { Bottom } \\
\text { sediments }\end{array}$ & $\begin{array}{c}340- \\
710\end{array}$ & $\begin{array}{c}21.4^{-} \\
82\end{array}$ & $\begin{array}{c}24,7^{-} \\
137\end{array}$ & $\begin{array}{l}0.09- \\
3.53\end{array}$ & $\begin{array}{c}0.25^{-} \\
1.4\end{array}$ & $<3$ \\
\hline $\begin{array}{l}\text { Fish (fresh } \\
\text { weight) }\end{array}$ & $\begin{array}{c}102.6- \\
120\end{array}$ & $<1.2$ & $<1.2$ & $\begin{array}{l}0.03^{-} \\
1.55\end{array}$ & $<0.4$ & - \\
\hline $\begin{array}{l}\text { Aquatic } \\
\text { flora }\end{array}$ & 134.5 & $<1.2$ & $<1.4$ & 9.7 & $<0.3$ & $<3$ \\
\hline $\begin{array}{l}\text { Drinking } \\
\text { water }\end{array}$ & $\begin{array}{c}0.87- \\
1.1\end{array}$ & $\begin{array}{l}0.11- \\
0.71\end{array}$ & $\begin{array}{l}0.2- \\
0.33\end{array}$ & $\begin{array}{l}0.01- \\
0.07\end{array}$ & 0.27 & $<3$ \\
\hline \multicolumn{7}{|c|}{ June, 2017} \\
\hline $\begin{array}{l}\text { Surface } \\
\text { water of } \\
\text { Padma }\end{array}$ & $\begin{array}{l}1.19^{-} \\
6.99\end{array}$ & $<0.5$ & $<0.5$ & $\begin{array}{l}0.013^{-} \\
0.041\end{array}$ & $\begin{array}{c}0.029- \\
0.114\end{array}$ & $<3$ \\
\hline $\begin{array}{l}\text { Bottom } \\
\text { sediments }\end{array}$ & $\begin{array}{c}350^{-} \\
85^{2}\end{array}$ & $\begin{array}{c}24.8- \\
122\end{array}$ & $\begin{array}{c}21.5^{-} \\
211\end{array}$ & $\begin{array}{l}0.2- \\
0.99\end{array}$ & $\begin{array}{l}0.5^{-} \\
2.83\end{array}$ & $\begin{array}{l}12.21- \\
30.84\end{array}$ \\
\hline Fish & $\begin{array}{l}77.7^{-} \\
124.1\end{array}$ & $<1.4$ & $<2.4$ & $\begin{array}{l}0.02- \\
0.24\end{array}$ & $\begin{array}{c}0.26- \\
0.3\end{array}$ & - \\
\hline $\begin{array}{l}\text { Aquatic } \\
\text { flora }\end{array}$ & $\begin{array}{l}347^{-} \\
1431\end{array}$ & $\begin{array}{l}8.7- \\
41.7\end{array}$ & $\begin{array}{l}17.1- \\
70.3\end{array}$ & $\begin{array}{l}0.38- \\
3.89\end{array}$ & $0.4-1$ & $<3$ \\
\hline $\begin{array}{l}\text { Drinking } \\
\text { water }\end{array}$ & 1.02 & $<0.2$ & $<0.11$ & $\begin{array}{c}0.041- \\
0.043\end{array}$ & $\begin{array}{c}0.033^{-} \\
0.06\end{array}$ & $<3$ \\
\hline
\end{tabular}

Studies on the content of radionuclides in drinking water were conducted in 1998 [15]. In the Kushtia and Rajahi regions, sampling at that time showed ${ }^{232} \mathrm{Th}$ content in drinking water in the range 0.25-0.27 Bq/L, ${ }^{40} \mathrm{~K}$ content ranged from 7.95 to $8.52 \mathrm{~Bq} / \mathrm{L}$. The results obtained during the radioecological monitoring of 2014-2017 correlate with data obtained previously. The content of radionuclides in drinking water and fish 
R. Mikailova et al., The programme of the radioecological monitoring..., RAP Conf. Proc., vol. 4, 2019, 108-112

does not exceed the requirements of the Russian sanitary and hygienic standards and international standards $[9,10,16]$.

The work on determining radiation levels at the site and in the area of the proposed Rooppur NPP location, conducted by Bangladesh's Atomic Energy Commission specialists presented the results of measuring the content of natural radionuclides in water samples [17]. In the framework of this study, specialists determined the content of ${ }^{238} \mathrm{U},{ }^{232} \mathrm{Th}$, and ${ }^{40} \mathrm{~K}$ in water samples. The concentrations of these radionuclides varied from 0.11 to $0.21 \mathrm{~Bq} / \mathrm{L}$ for ${ }^{238} \mathrm{U}$, from 0.13 to $0.30 \mathrm{~Bq} / \mathrm{L}$ for ${ }^{232} \mathrm{Th}$, and from 0.30 to $0.47 \mathrm{~Bq} / \mathrm{L}$ for $4^{\circ} \mathrm{K}$. Measurements of 2014-2017 showed that there were no significant changes in the background contents of natural radionuclides, except $4^{\circ} \mathrm{K}$. The average ${ }^{40} \mathrm{~K}$ content in December 2016 was 1.05 Bq/L, and in June 2017 it increased to $2.54 \mathrm{~Bq} / \mathrm{L}$. The global natural background of tritium is assumed to be $(2.2 \pm 0.7) \mathrm{Bq} / \mathrm{L}$ while the technogenic background is $5 \mathrm{~Bq} / \mathrm{L}$. Thus, the tritium content in the surface waters of the Padma River in the vicinity of the Rooppur NPP is below the average global value and several orders of magnitude below the level demanding intervention, according to the Russian radiation safety legislation. The same situation was observed for other technogenic radionuclides $\left({ }^{90} \mathrm{Sr}\right.$ and $\left.{ }^{137} \mathrm{Cs}\right)$. The content of ${ }^{90} \mathrm{Sr}$ and ${ }^{137 \mathrm{Cs}}$ was relatively low and averaged 0.06 and $0.07 \mathrm{~Bq} / \mathrm{L}$, respectively.

No studies were conducted on the content of radionuclides in bottom sediments in the area of the Rooppur NPP, but in 2017, there was published a paper on the content of natural radionuclides in the bottom sediments of the Brahmaputra River [18]. The average content of ${ }^{232} \mathrm{Th}$ and ${ }^{40} \mathrm{~K}$ was 113 and 1002 $\mathrm{Bq} / \mathrm{kg}$, respectively. The values of the content of natural radionuclides in bottom sediments in the Padma river basin obtained during radioecological monitoring are comparable with the results of Khalil et al. It should also be noted that changes in the radionuclide content in bottom sediments and higher aquatic vegetation are seasonal. During the dry season, the concentration of natural radionuclides in these samples decreased, and during the rainy period, it increased due to the flushing of soil and rock particles into water bodies.

\section{CONCLUSION}

According to the results of the radioecological monitoring of water ecosystems in the $30-\mathrm{km}$ zone of the Rooppur NPP conducted in 2014-2017, it can be concluded that the environmental situation in this region is safe. The established monitoring network will allow the observation of changes in the $30-\mathrm{km}$ zone of the Rooppur NPP and the identification of the impact caused by NPP's operation on the environmental situation in the region.

Acknowledgements: This work was supported by the Russian Scientific Foundation under grant No. 18-19-0oo16.

\section{REFERENCES}

1. R. Karim et al., "Nuclear energy development in Bangladesh: A study of opportunities and challenges," Energies, vol. 11, no. 7, Jun. 2018. DOI: $10.3390 /$ en 11071672

2. А. В. Панов, Н. И. Санжарова, В. К. Кузнецов, С. И. Спиридонов, Д. Н. Курбаков, “Анализ подходов к радиационно-экологическому мониторингу в районах размещения ядерно- и радиационноопасных объектов. Обзор,” Бюллетень Национального Радиационно-Эпидемиологического Регистра, том 28, но. 3, 2019.

(A. V. Panov, N. I. Sanzharova, V. K. Kuznetsov, S. I. Spiridonov, D. N. Kurbakov, "Analysis of approaches to organization of radioecological monitoring on areas of nuclear and radiationhazardous facilities location. Review," Bull. National Radiation and Epidemiological Registry, vol. 28, no. 3, Moscow, Russia, 2019.)

DOI: 10.21870/0131-3878-2019-28-3-75-95

3. Санитарно-защитные зоны и зоны наблюдения радиационных объектов. Условия эксплуатации и обоснование границ, СП 2.6.1.2216-07, июня 27, 2007.

(Sanitary protection zones and observation zones of radiation objects. Operating conditions and justification of borders, SP 2.6.1.2216-07, Jun. 27, 2007.

Retrieved from:

https://files.stroyinf.ru/Data2/1/4293841/4293841228 .pdf

Retrieved on: Dec. 8, 2019

4. Programmes and systems for source and environmental radiation monitoring, Safety Reports Series no. 64, IAEA, Vienna, Austria, 2010. Retrieved from:

https://wwwpub.iaea.org/MTCD/Publications/PDF/Pub1427 web. pdf

Retrieved on: Aug. 22, 2019

5. Environmental and source monitoring for purposes of radiation protection: safety guide, Safety Standards Series no. RS-G-1.8, IAEA, Vienna, Austria, 2005. Retrieved from:

https://wwwpub.iaea.org/MTCD/publications/PDF/Pub1216 web. pdf

Retrieved on: Aug. 22, 2019

6. Инженерно-экологические изыскания для строительства, СП 11-102-97, Авг. 15, 1997.

(Engineering environmental site investigations for construction, SP 11-102-97, Aug. 15, 1997.)

Retrieved from: https://files.stroyinf.ru/Data2/1/4294851/4294851544 .pdf

Retrieved on: Aug. 22, 2019

7. Организация и проведение режимных наблюдений за состоянием и загрязнением поверхностных вод суши, РД 52.24.309-2016, Дец. 20, 2016.

(Organisation and conduct of operational monitoring of the state and pollution of surface waters, RD 52.24.309-2016, Dec. 20, 2016.)

Retrieved from:

https://pdf.standartgost.ru/catalog/Data2/1/4293748/ 4293748080.pdf

Retrieved on: Aug. 22, 2019

8. Охрана природы. Гидросфера. Правила контроля качества воды водоёмов и водотоков, ГОСТ 17.1.3.07-82, Янв. 1, 1983.

(Nature protection. Hydrosphere. Procedures for quality control of water in reservoirs and stream flows, GOST 17.1.3.07-82, Jan. 1, 1983.)

Retrieved from: http://docs.cntd.ru/document/gost-171-3-07-82

Retrieved on: Aug. 22, 2019 
R. Mikailova et al., The programme of the radioecological monitoring..., RAP Conf. Proc., vol. 4, 2019, 108-112

9. Нормы радиационной безопасности. Санитарные правила и нормативы (НРБ-99/2009), СанПиН 2.6.1.2523-09, июля 7, 2009.

(Radiation Safety Standards NRB-99/2009. Sanitary standards and regulations, SanPiN 2.6.1.2523-09, Jul. 7, 2009.)

Retrieved from:

http://docs.cntd.ru/document/902170553

Retrieved on: Aug. 22, 2019

10. Основные санитарные правила обеспечения радиационной безопасности (ОСПОРБ 99/2010), СП 2.6.1.2612-10, Авг. 11, 2010.

(Basic sanitary rules for ensuring radiation safety (OSPORB 99/2010), SP 2.6.1.2612-10, Aug. 11, 2010.)

Retrieved from:

https://files.stroyinf.ru/Data2/1/4293816/4293816468 .pdf

Retrieved on: Aug. 22, 2019

11. АЭС Руппур. Энергоблоки 1, 2. Предпроектная документация. Отчеты по инженерным изысканиям. Т. 5. Технический отчет инженерноэкологические изысканиям. Книга 2., АО Атомэнергопроект, Москва, Россия, 2014.

(Rooppur NPP. Units 1, 2. Pre-project documentation. Reports on the engineering surveys. V. 5. Technical report on engineering and environmental surveys. Book 2., Atomenergoproekt JSC, Moscow, Russia, 2014.)

12. АЭС Руппур. Энергоблоки 1,2. Предпроектная документация. Сводный технический отчёт. Экологический мониторинг в зо-км зоне площадки АЭС Руппур: комплексное обследование атмосферного воздуха, наземных и водных экосистем. Книги 1, 2., АО Атомэнергопроект, Москва, Россия, 2015.

(Rooppur NPP. Units 1, 2. Pre-project documentation. Consolidated technical report. Environmental monitoring in the $30-\mathrm{km}$ zone of the Rooppur NPP site: a comprehensive survey of atmospheric air, terrestrial and aquatic ecosystems. Books 1, 2. Atomenergoproekt JSC, Moscow, Russia, 2015.)

13. АЭС Руппур. Энергоблоки 1,2. Технический отчёт. Экологический мониторинг на площадке АЭС Pуппур в 2016 г. Книги 1, 2., АО Атомэнергопроект, Москва, Россия, 2017.

(Rooppur NPP. Units 1, 2. Technical report. Environmental monitoring of the Rooppur NPP site in 2016. Books 1, 2., Atomenergoproekt JSC, Moscow, Russia, 2017.)

14. АЭС Руппур. Энергоблоки 1,2. Технический отчёт. Экологический мониторинг на площадке АЭС Pуппур в 2017 г. Книги 1, 2., АО Атомэнергопроект, Москва, Россия, 2017.

Rooppur NPP. Units 1, 2. Technical report. Environmental monitoring of the Rooppur NPP site in 2017. Books 1, 2., Atomenergoproekt JSC, Moscow, Russia, 2017.

15. S. R. Chakraborty, A. S. Mollah, A. Begum, G. U. Ahmad, "Radioactivity in Drinking Water of Bangladesh," Jpn. J. Health Phys., vol. 40, no. 2, pp. $191-201,2005$. DOI: $10.5453 /$ jhps.40.191

16. General Standard For Contaminants And Toxins In Food And Feed, CODEX STAN 193-1995, 2015.

Retrieved from:

http://www.fao.org/input/download/standards/17/CX S_193e_2015.pdf

Retrieved on: Dec. 8, 2019

17. A. S. Mollah, S. R. Chakraborty, "Radioactivity and Radiation Levels in and around the Proposed Nuclear Power Plant Site at Rooppur," Jpn. Health J. Phys., vol. 44, no. 4, pp. $408-413,2009$.

DOI: $10.5453 /$ jhps. 44.408

18. M. I. Khalil et al., "Assessment of natural radioactivity levels and identification of minerals in Brahmaputra (Jamuna) river sand and sediment, Bangladesh," Radiat. Prot. Environ., vol. 39, no. 4, pp. $204-211$, 2016.

DOI: $10.4103 / 0972-0464.199980$ 